\title{
Correction to: Modeling Axonal Plasticity in Artificial Neural Networks
}

\author{
James Ryland ${ }^{1}$ (D) \\ Published online: 15 June 2021 \\ (c) Springer Science+Business Media, LLC, part of Springer Nature 2021
}

\section{Correction to: Neural Processing Letters (2021) 53:1119-1146 https://doi.org/10.1007/s11063-021-10433-w}

In the original publication, the reference order has been published incorrectly. Here is the correct order for the inline citations in the paper.

\section{References}

1. Hubel DH, Wiesel TN (1962) Receptive fields, binocular interaction and functional architecture in the cat's visual cortex. J Physiol 160(1):106-154

2. Hubel DH, Wiesel TN (1965) Receptive fields and function architecture in two nonstriate visual ares (18 and 19) or the cat. J Neurophysiol 28(2):229-289

3. Quinlan PT (1998) Structural change and development in real and artificial neural networks. Neural Netw 11(4):577-599

4. McLaughlin T, O'Leary DDM (2005) Molecular gradients and development of retinotopic maps. Annu Rev Neurosci 28(1):327-355

5. Price DJ, Kennedy H, Dehay C, Zhou L, Mercier M, Jossin Y, Goffinet AM, Tissir F, Blakey D, Molnár Z (2006) The development of cortical connections. Eur J Neurosci 23(4):910-920

6. Sperry RW (1963) Chemoaffinity in the orderly growth of nerve fiber patterns and connections. Proc Natl Acad Sci 50(4):703-710

7. Gierer A (1987) Directional cues for growing axons forming the retinotectal projection. Development 101(3):479-489

8. Gierer A, Lewis W (1983) Model for the retino-tectal projection. Proc R Soc Lond Ser B Biol Sci 218(1210):77-93

9. Bishop KM, Goudreau G, O'Leary DDM (2000) Regulation of area identity in the mammalian neocortex by Emx2 and Pax6. Science 288(5464):344-349

10. Bishop KM, Rubenstein JLR, O'Leary DDM (2002) Distinct actions of Emx1, Emx2, andPax6 in regulating the specification of areas in the developing neocortex. J Neurosci 22(17):7627-7638

11. Bishop KM, Garel S, Nakagawa Y, Rubenstein JLR, O'Leary DDM (2003) Emx1 and Emx2 cooperate to regulate cortical size, lamination, neuronal differentiation, development of cortical efferents, and thalamocortical pathfinding. J Comp Neurol 457(4):345-360

The original article can be found online at https://doi.org/10.1007/s11063-021-10433-w.

James Ryland

jwr071000@utdallas.edu

1 Department of Behavioral and Brain Sciences, University of Texas at Dallas, Richardson, TX, USA 
12. Fukuchi-Shimogori T, Grove EA (2001) Neocortex patterning by the secreted signaling molecule FGF8. Science 294(5544):1071-1074

13. Fukuchi-Shimogori T, Grove EA (2003) Emx2 patterns the neocortex by regulating FGF positional signaling. Nat Neurosci 6(8):825-831

14. Hamasaki T, Leingärtner A, Ringstedt T, O’Leary DDM (2004) EMX2 Regulates sizes and positioning of the primary sensory and motor areas in neocortex by direct specification of cortical progenitors. Neuron 43(3):359-372

15. Gogolla N, Galimberti I, Caroni P (2007) Structural plasticity of axon terminals in the adult. Curr Opin Neurobiol 17(5):516-524

16. Meyer MP, Smith SJ (2006) Evidence from in vivo imaging that synaptogenesis guides the growth and branching of axonal arbors by two distinct mechanisms. J Neurosci 26(13):3604-3614

17. Portera-Cailliau C, Weimer RM, De Paola V, Caroni P, Svoboda K (2005) Diverse modes of axon elaboration in the developing neocortex. PLoS Biol 3(8):8

18. Ruthazer ES, Akerman CJ, Cline HT (2003) Control of axon branch dynamics by correlated activity in vivo. Science 301(5629):66-70

19. Simon DK, Leary DD (1992) Development of topographic order in the mammalian retinocollicular projection. J Neurosci 12(4):1212-1232

20. Simon DK, O'Leary DDM (1992) Influence of position along the medial-lateral axis of the superior colliculus on the topographic targeting and survival of retinal axons. Dev Brain Res 69(2):167-172

21. Simon DK, O'Leary DDM (1992) Responses of retinal axons in vivo and in vitro to position-encoding molecules in the embryonic superior colliculus. Neuron 9(5):977-989

22. Yates PA, Holub AD, McLaughlin T, Sejnowski TJ, O’Leary DDM (2004) Computational modeling of retinotopic map development to define contributions of EphA-ephrinA gradients, axon-axon interactions, and patterned activity. J Neurobiol 59(1):95-113

23. Crowley JC, Katz LC (2000) Early development of ocular dominance columns. Science 290(5495):1321-1324

24. Crair MC, Gillespie DC, Stryker MP (1998) The role of visual experience in the development of columns in cat visual cortex. Science 279(5350):566-570

25. Chapman B, Jacobson MD, Reiter HO, Stryker MP (1986) Ocular dominance shift in kitten visual cortex caused by imbalance in retinal electrical activity. Nature 324(6093):154-156

26. Innocenti GM, Price DJ (2005) Exuberance in the development of cortical networks. Nat Rev Neurosci 6(12):955-965

27. Qiao Q, Ma L, Li W, Tsai J-W, Yang G, Gan W-B (2016) Long-term stability of axonal boutons in the mouse barrel cortex. Dev Neurobiol 76(3):252-261

28. De Paola V, Holtmaat A, Knott G, Song S, Wilbrecht L, Caroni P, Svoboda K (2006) Cell type-specific structural plasticity of axonal branches and boutons in the adult neocortex. Neuron 49(6):861-875

29. Marik SA, Yamahachi H, McManus JNJ, Szabo G, Gilbert CD (2010) Axonal dynamics of excitatory and inhibitory neurons in somatosensory cortex. PLoS Biol 8(6):1-16

30. Srivastava N, Hinton G, Krizhevsky A, Sutskever I, Salakhutdinov R (2014) Dropout: a simple way to prevent neural networks from overfitting. J Mach Learn Res 15(1):1929-1958

31. Fukushima K (1980) Neocognitron: a self-organizing neural network model for a mechanism of pattern recognition unaffected by shift in position. Biol Cybern 36(4):193-202

32. Krizhevsky A, Sutskever I, Hinton GE (2012) ImageNet classification with deep convolutional neural networks. Adv Neural Inf Process Syst 25:1097-1105

33. Yamins DL, DiCarlo JJ (2016) Using goal-driven deep learning models to understand sensory cortex. Nat Neurosci 19:356-365

34. Fraser SE, Perkel DH (1990) Competitive and positional cues in the patterning of nerve connections. J Neurobiol 21(1):51-72

35. Godfrey KB, Eglen SJ, Swindale NV (2009) A multi-component model of the developing retinocollicular pathway incorporating axonal and synaptic growth. PLoS Comput Biol 5(12):1-22

36. Simpson HD, Goodhill GJ (2011) A simple model can unify a broad range of phenomena in retinotectal map development. Biol Cybern 104(1):9-29

37. Gebhardt C, Bastmeyer M, Weth F (2012) Balancing of ephrin/Eph forward and reverse signaling as the driving force of adaptive topographic mapping. Development 139(2):335-345

38. Benson DL, Colman DR, Huntley GW (2001) Molecules, maps and synapse specificity. Nat Rev Neurosci 2(12):899-909

39. Burt P, Adelson E (1983) The Laplacian pyramid as a compact image code. IEEE Trans Commun 31(4):532-540

40. Wandell BA, Dumoulin SO, Brewer AA (2007) Visual field maps in human cortex. Neuron 56(2):366-383 
41. Dougherty RF, Koch VM, Brewer AA, Fischer B, Modersitzki J, Wandell BA (2003) Visual field representations and locations of visual areas v1/2/3 in human visual cortex. J Vis 3(10):586-598

42. Engel SA, Glover GH, Wandell BA (1997) Retinotopic organization in human visual cortex and the spatial precision of functional MRI. Cereb Cortex 7(2):181-192

43. Qiu A, Rosenau BJ, Greenberg AS, Hurdal MK, Barta P, Yantis S, Miller MI (2006) Estimating linear cortical magnification in human primary visual cortex via dynamic programming. Neuroimage 31(1):125-138

44. Issa NP, Trepel C, Stryker MP (2000) Spatial frequency maps in cat visual cortex. J Neurosci 20(22):8504

45. Ribot J, Aushana Y, Bui-Quoc E, Milleret C (2013) Organization and origin of spatial frequency maps in cat visual cortex. J Neurosci 33(33):13326-13343

46. Hubel DH, Wiesel TN (1972) Laminar and columnar distribution of geniculo-cortical fibers in the macaque monkey. J Comp Neurol 146(4):421-450

47. LeVay S, Hubel DH, Wiesel TN (1975) The pattern of ocular dominance columns in macaque visual cortex revealed by a reduced silver stain. J Comp Neurol 159(4):559-575

48. Le Vay S, Wiesel TN, Hubel DH (1980) The development of ocular dominance columns in normal and visually deprived monkeys. J Comp Neurol 191(1):1-51

49. Obermayer K, Blasdel GG (1993) Geometry of orientation and ocular dominance columns in monkey striate cortex. J Neurosci 13(10):4114-4129

50. von der Malsburg C (1973) Self-organization of orientation sensitive cells in the striate cortex. Kybernetik 14(2):85-100

51. Sirosh J, Miikkulainen R (1994) Cooperative self-organization of afferent and lateral connections in cortical maps. Biol Cybern 71(1):65-78

52. Stevens JLR, Law JS, Antolík J, Bednar JA (2013) Mechanisms for stable, robust, and adaptive development of orientation maps in the primary visual cortex. J Neurosci 33(40):15747-15766

53. Hubel DH, Wiesel TN, Stryker MP (1978) Anatomical demonstration of orientation columns in macaque monkey. J Comp Neurol 177(3):361-379

54. Blasdel GG (1992) Orientation selectivity, preference, and continuity in monkey striate cortex. J Neurosci 12(8):3139-3161

55. Bonhoeffer T, Grinvald A (1991) Iso-orientation domains in cat visual cortex are arranged in pinwheel-like patterns. Nature 353(6343):429-431

56. Durbin R, Mitchison G (1990) A dimension reduction framework for understanding cortical maps. Nature 343(6259):644-647

57. Goodhill GJ, Cimponeriu A (2000) Analysis of the elastic net model applied to the formation of ocular dominance and orientation columns. Netw Comput Neural Syst 11(2):153-168

58. Miikkulainen R, Bednar JA, Choe Y, Sirosh J (2005) Computational maps in visual cortex. Springer, New York

59. Issa NP, Rosenberg A, Husson TR (2008) Models and measurements of functional maps in V1. J Neurophysiol 99(6):2745-2754

60. Bosking WH, Zhang Y, Schofield B, Fitzpatrick D (1997) Orientation selectivity and the arrangement of horizontal connections in tree shrew striate cortex. J Neurosci 17(6):2112-2127

61. Horton JC, Hocking DR (1996) Intrinsic variability of ocular dominance column periodicity in normal macaque monkeys. J Neurosci 16(22):7228-7339

62. Humphrey AL, Sur M, Uhlrich DJ, Sherman SM (1985) Projection patterns of individual X- and Y-cell axons from the lateral geniculate nucleus to cortical area 17 in the cat. J Comp Neurol 233(2):159-189

63. Levy M, Lu Z, Dion G, Kara P (2014) The shape of dendritic arbors in different functional domains of the cortical orientation map. J Neurosci 34(9):3231-3236

64. Elston GN, Rosa MG (1997) The occipitoparietal pathway of the macaque monkey: comparison of pyramidal cell morphology in layer III of functionally related cortical visual areas. Cereb Cortex 7(5):432-452

65. Chklovskii DB (2000) Optimal sizes of dendritic and axonal arbors in a topographic projection. J Neurophysiol 83(4):2113-2119

Publisher's Note Springer Nature remains neutral with regard to jurisdictional claims in published maps and institutional affiliations. 